ATONEMENT AND FORGIVENESS 
This page intentionally left blank 


\section{ATONEMENT AND FORGIVENESS}

A New Model for Black Reparations

Roy L. Brooks 
University of California Press

Berkeley and Los Angeles, California

University of California Press, Ltd.

London, England

(C) 2004 by the Regents of the University

of California

Library of Congress Cataloging-in-Publication Data

Brooks, Roy L. (Roy Lavon), 1950-.

Atonement and forgiveness : a new model for Black reparations / Roy L. Brooks.

p. $\mathrm{cm}$.

"George Gund Foundation imprint in African American studies."

Includes bibliographical references and index. ISBN 0-520-2394I-5 (alk. paper)

I. African Americans-Reparations.

2. Atonement. 3. Government liability-United States. I. Title.

EI85.89.R45B76 2004

$973^{\prime} .049673-\mathrm{dc22}$

2004041239

Manufactured in the United States of America

$\begin{array}{llllllllll}\text { I3 } & \text { I2 } & \text { II } & \text { IO } & 09 & 08 & 07 & 06 & 05 & 04\end{array}$

$\begin{array}{llllllllll}\text { IO } & 9 & 8 & 7 & 6 & 5 & 4 & 3 & 2 & \text { I }\end{array}$

The paper used in this publication meets the minimum requirements of ANSI/NISO Z39.48-1992 (R 1997) (Permanence of Paper). 
To Watson Branch, a friend, a scholar, and a beautiful person 
This page intentionally left blank 